\title{
ELECTRICAL CONDUCTIVITY OF SOIL IRRIGATED WITH SWINE WASTEWATER ESTIMATED BY TIME-DOMAIN REFLECTOMETRY ${ }^{(1)}$
}

\author{
Rosimaldo Soncela ${ }^{(2)}$, Silvio Cesar Sampaio ${ }^{(3)}$, Marcio Antonio Vilas Boas ${ }^{(3)}$, \\ Maria Hermínia Ferreira Tavares ${ }^{(3)}$, Claudinei Fonseca Souza ${ }^{(4)}$ \& Adriana \\ Smanhotto Soncela ${ }^{(5)}$
}

\begin{abstract}
SUMMARY
Wastewater application to soil is an alternative for fertilization and water reuse. However, particular care must be taken with this practice, since successive wastewater applications can cause soil salinization. Time-domain reflectometry (TDR) allows for the simultaneous and continuous monitoring of both soil water content and apparent electrical conductivity and thus for the indirect measurement of the electrical conductivity of the soil solution. This study aimed to evaluate the suitability of TDR for the indirect determination of the electrical conductivity $\left(\mathrm{EC}_{\mathrm{se}}\right)$ of the saturated soil extract by using an empirical equation for the apparatus TDR Trase 6050X1. Disturbed soil samples saturated with swine wastewater were used, at soil proportions of $0,0.45,0.90,1.80,2.70$, and $3.60 \mathrm{~m}^{3} \mathrm{~m}^{-3}$. The probes were equipped with three handmade $0.20 \mathrm{~cm}$ long rods. The fit of the empirical model that associated the TDR measured values of electrical conductivity $\left(\mathrm{EC}_{\mathrm{TDR}}\right)$ to $\mathbf{E C}_{\mathrm{se}}$ was excellent, indicating this approach as suitable for the determination of electrical conductivity of the soil solution.
\end{abstract}

Index terms: TDR, soil salinity, soil water content, water reuse.

\footnotetext{
(1) Part of the MS Dissertation of the first author through the Graduate Program in Agricultural Engineering, State University of Western Paraná (UNIOESTE). Received for publication in August 17, 2010 and approved for publication in May 6, 2011.

(2) Phd student, Graduate Program in Agricultural Engineering of UNIOESTE. CEP 85814-110 Cascavel (PR). E-mails: soncelar@hotmail.com; rsoncela@bol.com.br

(3) Professors, Graduate Program in Agricultural Engineering of UNIOESTE. E-mail: mhstavar@gmail.com

(4) Professor, Federal University of São Carlos. E-mail: cfsouza@cca.ufscar.br

(5) Post-doctoral student, Graduate Program in Agricultural Engineering of UNIOESTE. E-mail: adrianasmanhotto@hotmail.com
} 


\title{
RESUMO: CONDUTIVIDADE ELÉTRICA DE SOLO IRRIGADO COM ÁGUA RESIDUÁRIA DE SUINOCULTURA ESTIMADA POR REFLECTOMETRIA NO DOMÍNIO DO TEMPO
}

\begin{abstract}
A aplicação de água residuária no solo é uma forma alternativa de fertilização do solo e de reúso da água. Entretanto, deve-se dar especial atenção à técnica, devido ao fato de que sucessivas aplicações podem provocar a salinização do solo. A reflectometria no domínio do tempo (TDR) permite não apenas o monitoramento simultâneo e contínuo do teor de água e da condutividade elétrica aparente do solo, como também a determinação indireta da condutividade elétrica de sua solução. O presente trabalho teve por objetivo avaliar a viabilidade do emprego da TDR na determinação indireta da condutividade elétrica de um extrato de solo saturado $\left(C E_{\text {se }}\right)$, empregando-se uma equação empírica para o equipamento TDR Trase ${ }^{\circledR}$ modelo 6050X1. O experimento foi conduzido utilizando-se amostras deformadas de solo saturadas com água residuária da suinocultura nas proporções de 0, 0,45, 0,90, 1,80, 2,70 e $3,60 \mathrm{~m}^{3} \mathrm{~m}^{-3}$ de solo. As sondas utilizadas eram equipadas com três hastes de 0,20 $\mathrm{cm}$ de comprimento, montadas artesanalmente. O modelo empírico que associou valores da condutividade elétrica mensurado por meio da TDR $\left(C E_{T D R}\right)$ com $C E_{\text {se }}$ propiciou excelente ajuste, indicando a viabilidade da técnica na determinação da condutividade elétrica da solução do solo.
\end{abstract}

Termos de indexação: TDR, salinidade do solo, umidade do solo, reúso da água.

\section{INTRODUCTION}

Wastewater reuse in agriculture as a source of water and plant nutrients is one of the alternatives to deal with the environmental problem posed by the intensive piggery waste production.

The application of swine wastewater on soil is considered an effective form of pollution control and an alternative to the use of mineral fertilizers (Sampaio et al., 2010). However, the inadequate adoption of this procedure can increase the saline concentration of the soil solution, to values that can impair crop development. Thus, it is necessary to monitor soil salt concentrations from dissolved inorganic solutes, mainly $\mathrm{Na}^{+}, \mathrm{Ca}^{++}, \mathrm{Mg}^{++}, \mathrm{K}^{+}$, and anions $\mathrm{Cl}^{-}, \mathrm{SO}_{4}{ }^{-}, \mathrm{HCO}_{3}{ }^{-}, \mathrm{CO}_{3}{ }^{2-}$ (Rhoades, 1996).

Electrical conductivity is a regular parameter used to evaluate the salt contents of both soil and irrigation water. According to Embrapa (1997), the usual saturation-extract method for evaluating soil salinity is time and space-limited since its results represent the soil conditions at the sampling moment and for the tested soil volume. Time-domain reflectometry (TDR) may be a suitable procedure for the indirect determination of apparent soil electrical conductivity $\left(\mathrm{EC}_{\text {soil }}\right)$ under field conditions, not only in view of the real time readings but also of the minimal disturbance of the soil structure (Robinson et al., 2003; Jones \& Or, 2004; Nadler, 2004; Coelho et al., 2005; Souza et al., 2006). However, TDR devices must be calibrated to the specific characteristics of each soil (Hamed et al., 2003), by collecting equipment data and reference values and relating them (Cichota, 2003).
TDR also allows the simultaneous determination of the water content and apparent conductivity of soil $\left(\mathrm{EC}_{\text {soil }}\right)$ by measuring the displacement time of electromagnetic pulses in a transmission line consisting of steel rods of known sizes introduced into the soil (Topp et al., 1980; Dalton et al., 1984). However, to estimate this parameter, the characteristic probe impedance must be determined (Souza et al., 2006), which can be done when it is wrapped in a uniform dielectric material (Or et al., 2004).

In view of the potential advantages of TDR and the lack of research into the determination of salinity in wastewater-treated soils, the purpose of this study was to evaluate the suitability of TDR for the indirect determination of electric conductivity of the soil solution after swine wastewater application using an empirical equation for the TDR Trase ${ }^{\circledR}$ model $6050 X 1$.

\section{MATERIAL AND METHODS}

This study was conducted at the laboratory of Hydric Resources and Environmental Sanitation of the Graduate Program of Agricultural Engineering of the Universidade Estadual do Oeste do Parana (UNIOESTE), Paraná, Brazil. A TDR equipment Trase $^{\circledR}$ model $6050 \mathrm{X} 1$ was used to analyze air-dried and sieved (10 mesh) soil sampled from the surface layer $(0-20 \mathrm{~cm})$ of a Rhodic Acrudox soil (US Soil Taxonomy), basaltic substrate (Table 1), and swine wastewater (SW) processed in a biodigester (Table 2). 
Table 1. Chemical and particle-size distribution analysis of soil of the experimental area

\begin{tabular}{lc}
\hline Parameters & Value \\
\hline Sand (\%) & 5.90 \\
Silt (\%) & 14.62 \\
Clay (\%) & 79.48 \\
$\mathrm{pH}\left(\mathrm{CaCl}_{2}\right)$ & 4.40 \\
Electrical conductivity $\left(\mathrm{dS} \mathrm{m}^{-1}\right)$ & 0.518 \\
$\mathrm{OM}\left(\mathrm{g} \mathrm{dm}^{-3}\right)$ & 19.23 \\
$\mathrm{Al}\left(\mathrm{cmol}_{\mathrm{c}} \mathrm{dm}^{-3}\right)$ & 1.42 \\
$\mathrm{Al}+\mathrm{H}\left(\mathrm{cmol}_{\mathrm{c}} \mathrm{dm}^{-3}\right)$ & 8.36 \\
Phosphorus $\left(\mathrm{mg} \mathrm{dm}^{-3}\right)$ & 4.67 \\
Potassium $\left(\mathrm{cmol}_{\mathrm{c}} \mathrm{dm}^{-3}\right)$ & 0.19 \\
Sodium $\left(\mathrm{mg} \mathrm{dm}^{-3}\right)$ & 1.0 \\
Calcium $\left(\mathrm{cmol}_{\mathrm{c}} \mathrm{dm}^{-3}\right)$ & 1.58 \\
Magnesium $\left(\mathrm{cmol}_{\mathrm{c}} \mathrm{dm}^{-3}\right)$ & 0.78 \\
Copper $\left(\mathrm{mg} \mathrm{dm}^{-3}\right)$ & 10.43 \\
Zinc $\left(\mathrm{mg} \mathrm{dm}^{-3}\right)$ & 0.82 \\
Iron $\left(\mathrm{mg} \mathrm{dm}^{-3}\right)$ & 36.07 \\
\hline
\end{tabular}

Mehlich Extractor: $\mathrm{K}-\mathrm{P}-\mathrm{Fe}-\mathrm{Mn}-\mathrm{Cu}-\mathrm{Zn}$; Extractant $\mathrm{KCl}$ : $\mathrm{Ca}-\mathrm{Mg}-\mathrm{Al}$. Particle-size distribution analysis: Bouyoucos densimeter method.

Table 2. Characteristics of the experimental swine wastewater

\begin{tabular}{lr}
\hline \multicolumn{1}{c}{ Parameters } & Value \\
\hline $\mathrm{pH}\left(\mathrm{CaCl}_{2}\right)$ & 7.73 \\
Electrical conductivity $\left(\mathrm{dS} \mathrm{m}^{-1}\right)$ & 4.98 \\
Turbidity & 459.33 \\
Biochemical Oxygen Demand $\left(\mathrm{mg} \mathrm{L}^{-1}\right)$ & 671.04 \\
Chemical Oxygen Demand $\left(\mathrm{mg} \mathrm{L}^{-1}\right)$ & 1444.07 \\
Total phosphorus $\left(\mathrm{mg} \mathrm{L}^{-1}\right)$ & 92.19 \\
Soluble orthophosphate $\left(\mathrm{mg} \mathrm{L}^{-1}\right)$ & 96.86 \\
Potassium $\left(\mathrm{mg} \mathrm{L}^{-1}\right)$ & 543.33 \\
Sodium $\left(\mathrm{mg} \mathrm{L}^{-1}\right)$ & 18.20 \\
Calcium $\left(\mathrm{mg} \mathrm{L}^{-1}\right)$ & 50.97 \\
Magnesium $\left(\mathrm{mg} \mathrm{L}^{-1}\right)$ & 23.77 \\
Copper $\left(\mathrm{mg} \mathrm{L}^{-1}\right)$ & 0.20 \\
Zinc $\left(\mathrm{mg} \mathrm{L}^{-1}\right)$ & 0.17 \\
Sodium adsorption rate & 0.53 \\
\hline
\end{tabular}

The soil samples were packed in $0.0075 \mathrm{~m}^{3} \mathrm{PVC}$ columns that were thumped against a rubber mat to settle the particles and avoid voids, to achieve an approximate density of $1.10 \mathrm{~g} \mathrm{~cm}^{-3}$. Each soil column was saturated with deionized water using a $25 \mathrm{~mm}$ PVC tube perforated every $5 \mathrm{~cm}$ and set in the center of the column to prevent salt leaching.

The volume of swine wastewater added to the soil columns was defined based on the electric conductivity of swine wastewater and was equivalent to rates of 0 (T1), 0.45 (T2), 0.90 (T3), 1.8 (T4), 2.7 (T5), and 3.6 (T6) $\mathrm{m}^{3} \mathrm{~m}^{-3}$ of soil. For each treatment, three $0.0075 \mathrm{~m}^{3}$ PVC columns were used, with four TDR probes installed in each one.

The probes used in the experiment were handmade and previously tested according to Souza et al. (2006).
The apparent dielectric constant $(\mathrm{Ka})$ and the soil volumetric moisture were determined daily based on the volume, using an accuracy balance for 20 days. The model capacity to estimate volumetric moisture was evaluated using the determination coefficient and linear fitting. Next, the probes were standardized based on linear and angular coefficients of the calibration equation for soil volumetric moisture determination. For this purpose, the statistical quality control tool for individual measurements of Shewhart (Montgomery, 2004) was applied, using MINITAB software.

The data were monitored daily with TDR equipment (Trase System 6050X1) using software INFOSYS-TDR (Tavares et al., 2006).

To estimate the apparent electric conductivity, an impedance probe (Zo) and Equation 1 (Or et al., 2004) was used:

$$
Z_{0}=Z_{u} \sqrt{k}\left(\frac{1+V_{1}}{1+2 V_{0}-V_{1}}\right)
$$

where $Z_{0}=$ characteristic impedance of the probe $(\Omega)$; $\mathrm{Z}_{\mathrm{u}}=$ cable impedance $\sim 50 \Omega ; \mathrm{V}_{0}$ and $\mathrm{V}_{1}=$ relative tension; $\mathrm{K}=$ dielectric constant (in distilled water).

With these data, the TDR graphs, the probe impedance values and the electric conductivity of the soil volume $\left(\mathrm{EC}_{\mathrm{TDR}}\right)$ were estimated with Equation 2 (Giese \& Tiemann, 1975).

$$
C E_{T D R}=\frac{Z_{0}}{120 \pi Z_{u} L}\left(\frac{2 V_{0}}{V_{\mathrm{inf}}}-1\right)
$$

where $\mathrm{L}=$ probe length, $\mathrm{m}, \mathrm{Z}_{0}=$ probe characteristic impedance determined in distilled water (Souza et al., 2004), $\mathrm{Z}_{\mathrm{u}}=$ cable impedance $(\sim 50 \Omega) ; \mathrm{V}_{0}$ and $\mathrm{V}_{\text {inf }}=$ relative tension.

The plots of the TDR Trase $6050 \mathrm{X} 1$ data used in the determination of $\mathrm{V}_{0} ; \mathrm{V}_{1}$; and $\mathrm{V}_{\text {inf }}$ are shown in Figure 1.

The linear correlation between $\mathrm{EC}_{\mathrm{TDR}}$, estimated with equation 2 , and the $\beta$ coefficient, determined as the ratio between $V_{0}$ and $V_{\text {inf }}$; were investigated, aiming at an easy indirect determination of $\mathrm{EC}_{\mathrm{TDR}}$ using the collected data.

Next, the linear models were fitted for the soil volumetric moisture $\left(\theta_{\mathrm{s}}\right)$ and $\mathrm{EC}_{\mathrm{TDR}}$, (Equation 3 ) for all treatments.

$$
C E_{T D R}=\alpha+\mathrm{b} \theta \mathrm{s}
$$

where $\alpha$ and $b=$ fitting parameters; $\theta_{\mathrm{s}}=$ soil volumetric moisture $\left(\mathrm{cm}^{3} \mathrm{~cm}^{-3}\right)$.

Statistical tests using the F-Snedecor distribution and t-Student comparison were performed at $5 \%$ significance level to verify significant differences between the fitted models for the respective treatments. 


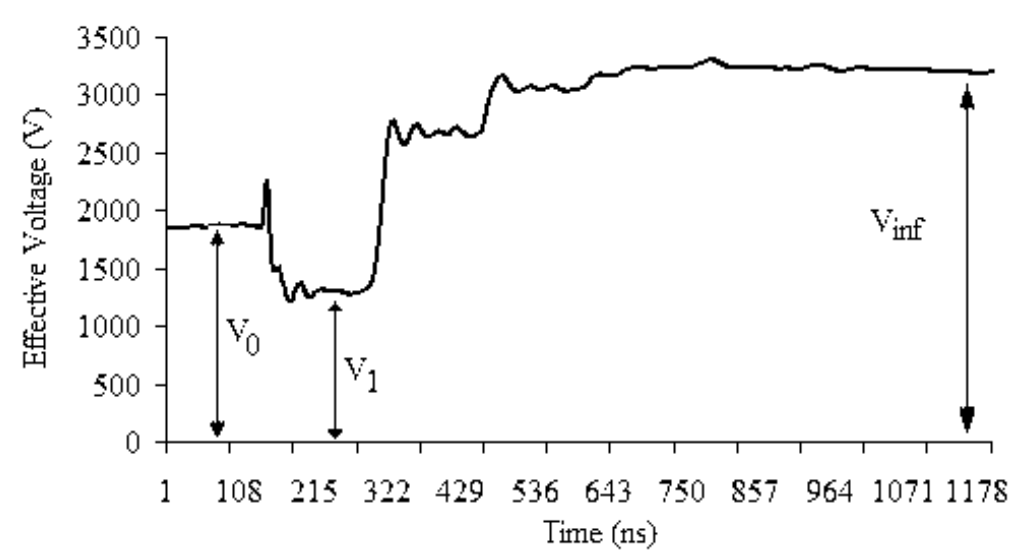

Figure 1. TDR Trase $6050 \mathrm{X} 1$ plot used in the determination of $V_{0}, V_{1}$ and $V_{\text {inf }}$.

The F-Snedecor test was used to verify the homogeneity of the data set variances between the two linear models. After verifying the homogeneity, the comparison test was applied to the two linear models.

After the above analysis, a model for the determination of $\mathrm{EC}_{\mathrm{se}}$ from $\mathrm{EC}_{\mathrm{TDR}}$ was fitted and tested at $5 \%$ significance.

\section{RESULTS AND DISCUSSION}

As the TDR Trase 6050 X1 built-in equation was not applicable to the handmade probes for the investigated Rhodic Acrudox soil, a new equation was determined. In this study, the mean apparent dielectric constant $(\mathrm{Ka})$ in water, obtained for all probes, was 75.6, with a coefficient of variation of $2.49 \%$, which is considered low and indicates homogeneous data (Gomes, 2000; Villwock et al., 2004). The linear coefficient $a$ and the angular coefficient $b$ values were obtained by linear regression for each probe. The probes were standardized by
Shewhart statistical quality control, as shown in figures 2 and 3 (Montgomery, 2004).

For the linear coefficients, figure 2 shows that the values of observations $16,17,18,19,20,31$, and 76 (probes 24, 25, 26, 28, 29, 48, 04) were outside the control limits (High Control Limit [HCL] and Low Control Limit [LCL]). These probes were therefore excluded from the experiment. Observations 16, 17, 19 , and 20 (probes 24, 25, 28, and 29) were also outside the quality control limits for the angular coefficients, thus demonstrating the reliability of the methodology proposed by Souza et al. (2006), used to make the probes.

The model fitted to the grouped data indicates a significant linear correlation between the apparent dielectric constant and the volumetric moisture of the soil (Figure 4), demonstrating that it is possible to use the coefficient of the handmade probe to determine soil volumetric moisture (Silva \& Gervásio, 1999; Tommaselli \& Bacchi, 2001; VillwocK et al., 2004; Santoro et al., 2009).

Figure 5 shows the correlation between the $\beta$ coefficient and $\mathrm{EC}_{\mathrm{TDR}}$ for the different salinity levels

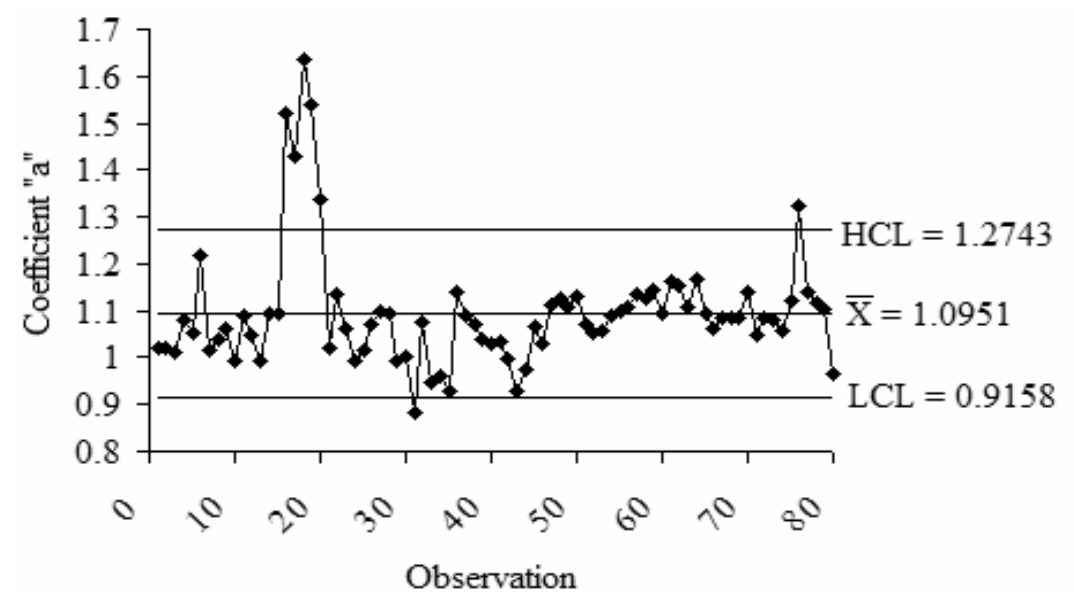

Figure 2. Statistical quality control for the linear coefficient. 
in the different treatments with SW. It also shows that the angular and linear coefficients, and the obtained model, are significant and have a high level of reliability. The coefficient of determination obtained was excellent $\left(\mathrm{R}^{2}=0.997\right)$. These results demonstrate a linear correlation between the $\beta$ coefficient and $\mathrm{EC}_{\mathrm{TDR}}$ and that it is possible to use the $\beta$ coefficient to determine $\mathrm{EC}_{\mathrm{TDR}}$.

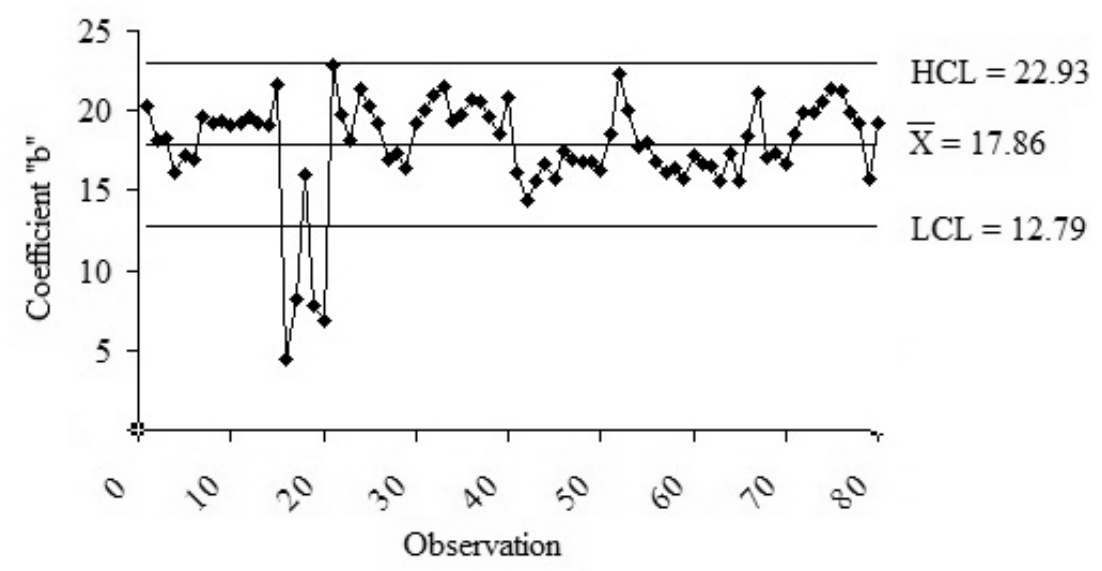

Figure 3. Statistical quality control for the angular coefficient.

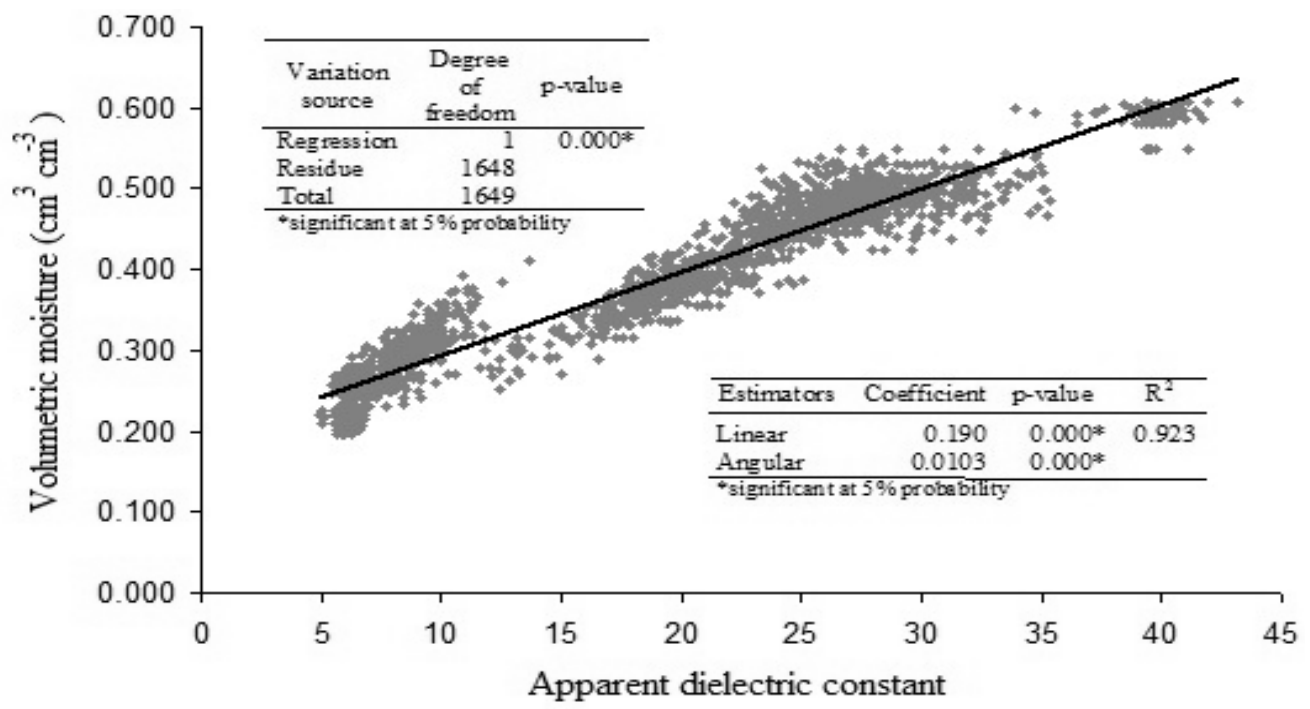

Figure 4. Model fitted for the grouped data.

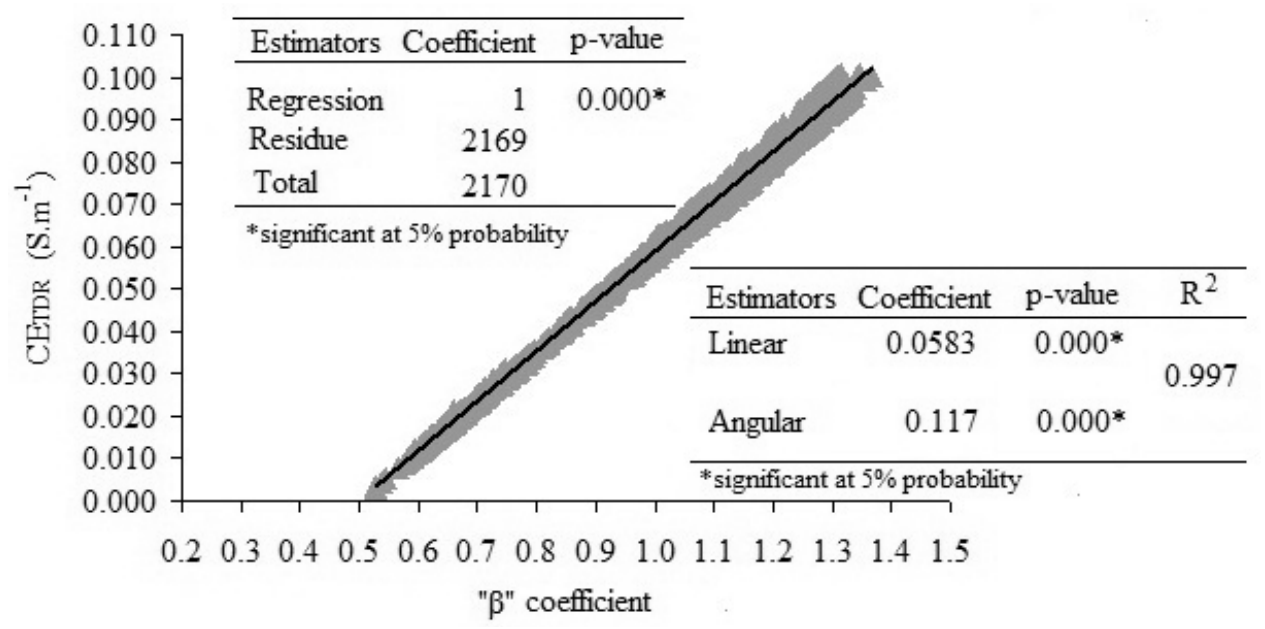

Figure 5. Linear correlation between the â coefficient and $\mathrm{EC}_{\mathrm{TDR}}$. 
Table 3 shows the results of the F-Snedecor and tStudent comparison tests of the fitted models for $\theta_{\mathrm{s}}$ and $\mathrm{EC}_{\mathrm{TDR}}$ for all treatments.

The variance of the treatments was equal for the F test, indicating that it is possible to use the t-Student test to compare the linear models. The test indicates that all models are equal, since the angular and linear coefficients were equal.

Thus, based on the analyses in figure 5 and table 3 , it was possible to construct a linear model to estimate $\mathrm{EC}_{\mathrm{es}}$ from $\mathrm{EC}_{\mathrm{TDR}}$, as shown in figure 6 .
The fitted model and the angular and linear coefficients were significant at $5 \%$ level. The model fitting was also demonstrated by the high coefficient of determination $\left(\mathrm{R}^{2}=0.956\right)$.

Thus, the analyses show that there is a functional relationship in the estimation of $\mathrm{EC}_{\mathrm{se}}$ from $\mathrm{EC}_{\mathrm{TDR}}$, corroborating Queiroz (2005) and Souza et al. (2007).

The TDR technique can therefore substitute the soil saturated extract method of soil salinity analysis, since the estimation of $\mathrm{EC}_{\mathrm{TDR}}$ is practical, accurate and non-destructive.

Table 3. Comparison test of the angular and linear coefficients of graphs of wastewater treatments considering the soil electric conductivity obtained by TDR $\left(\mathrm{S} \mathrm{m}^{-1}\right)$ and volumetric moisture $\left(\mathrm{cm}^{3} \mathrm{~cm}^{-3}\right)$

\begin{tabular}{|c|c|c|c|c|c|c|}
\hline & $\begin{array}{l}\text { Angular } \\
\text { Coef. (b) }\end{array}$ & $\begin{array}{c}\text { Linear } \\
\text { Coef. (a) }\end{array}$ & RMS & $\begin{array}{c}\text { F Test } \\
\text { RMS }\end{array}$ & $\begin{array}{c}\text { T Test } \\
\text { (b) }\end{array}$ & $\begin{array}{c}\text { T Test } \\
\text { (a) }\end{array}$ \\
\hline $\mathrm{T} 1$ & -0.0793 & 0.0680 & 0.000003 & $|0.77 \mathrm{Fc}|<1.75 \mathrm{Ft}$ & $|0.80 \mathrm{Tc}|<1.98 \mathrm{Tt}$ & $|0.006 \mathrm{Tc}|<1.98 \mathrm{Tt}$ \\
\hline $\mathrm{T} 2$ & -0.0747 & 0.0928 & 0.000004 & $\mathrm{QME}_{\mathrm{T} 1}=\mathrm{QME}_{\mathrm{T} 2}$ & $\mathrm{~B}_{\mathrm{T} 1}=\mathrm{b} \mathrm{T} 2$ & $\mathrm{~A}_{\mathrm{T} 1}=\mathrm{a}_{\mathrm{T} 2}$ \\
\hline $\mathrm{T} 1$ & -0.0793 & 0.0680 & 0.000003 & $|0.43 \mathrm{Fc}|<1.65 \mathrm{Ft}$ & $|1.75 \mathrm{Tc}|>1.98 \mathrm{Tt}$ & $|0.001 \mathrm{Tc}|<1.98 \mathrm{Tt}$ \\
\hline T3 & -0.0673 & 0.1030 & 0.000007 & $\mathrm{QME}_{\mathrm{T} 1}=\mathrm{QME}_{\mathrm{T} 4}$ & $\mathrm{~B}_{\mathrm{T} 1}=\mathrm{bT}_{4}$ & $\mathrm{~A}_{\mathrm{T} 1}=\mathrm{a}_{\mathrm{T} 4}$ \\
\hline $\mathrm{T} 1$ & -0.0793 & 0.0680 & 0.000003 & $|0.41 \mathrm{Fc}|<1.61 \mathrm{Ft}$ & $|0.94 \mathrm{Tc}|<1.98 \mathrm{Tt}$ & $|0.005 \mathrm{Tc}|<1.98 \mathrm{Tt}$ \\
\hline $\mathrm{T} 4$ & -0.0719 & 0.1070 & 0.000008 & $\mathrm{QME}_{\mathrm{T} 1}=\mathrm{QME}_{\mathrm{T} 3}$ & $\mathrm{~B}_{\mathrm{T} 1}=\mathrm{b}_{\mathrm{T} 3}$ & $\mathrm{~A}_{\mathrm{T} 1}=\mathrm{aT} 3$ \\
\hline $\mathrm{T} 1$ & -0.0793 & 0.0680 & 0.000003 & $|0.69 \mathrm{Fc}|<1.75 \mathrm{Ft}$ & $|1.19 \mathrm{Tc}|<1.98 \mathrm{Tt}$ & $|0.01 \mathrm{Tc}|<1.98 \mathrm{Tt}$ \\
\hline $\mathrm{T} 5$ & -0.0720 & 0.1180 & 0.000005 & $\mathrm{QME}_{\mathrm{T} 1}=\mathrm{QME}_{\mathrm{T} 5}$ & $\mathrm{~B}_{\mathrm{T} 1}=\mathrm{b}_{\mathrm{T} 5}$ & $\mathrm{~A}_{\mathrm{T} 1}=\mathrm{a}_{\mathrm{T} 5}$ \\
\hline $\mathrm{T} 1$ & -0.0793 & 0.0680 & 0.000003 & $|0.71 \mathrm{Fc}|<1.80 \mathrm{Ft}$ & $|1.60 \mathrm{Tc}|<1.98 \mathrm{Tt}$ & $|0.01 \mathrm{Tc}|<1.98 \mathrm{Tt}$ \\
\hline $\mathrm{T} 6$ & -0.0693 & 0.1250 & 0.000004 & $\mathrm{QME}_{\mathrm{T} 1}=\mathrm{QME}_{\mathrm{T} 6}$ & $\mathrm{~B}_{\mathrm{T} 1}=\mathrm{b}_{\mathrm{T} 6}$ & $\mathrm{~A}_{\mathrm{T} 1}=\mathrm{aT} 6$ \\
\hline $\mathrm{T} 2$ & -0.0747 & 0.0928 & 0.000004 & $|0.57 \mathrm{Fc}|<1.74 \mathrm{Ft}$ & $|1.03 \mathrm{Tc}|<1.98 \mathrm{Tt}$ & $|0.03 \mathrm{Tc}|<1.98 \mathrm{Tt}$ \\
\hline $\mathrm{T} 3$ & -0.0673 & 0.1030 & 0.000007 & $\mathrm{QME}_{\mathrm{T} 2}=\mathrm{QME}_{\mathrm{T} 4}$ & $\mathrm{~B}_{\mathrm{T} 2}=\mathrm{b}_{\mathrm{T} 4}$ & $\mathrm{~A}_{\mathrm{T} 2}=\mathrm{a}_{\mathrm{T} 4}$ \\
\hline $\mathrm{T} 2$ & -0.0747 & 0.0928 & 0.000004 & $|0.53 \mathrm{Fc}|<1.74 \mathrm{Ft}$ & $|0.34 \mathrm{Tc}|<1.98 \mathrm{Tt}$ & $|0.04 \mathrm{Tc}|<1.98 \mathrm{Tt}$ \\
\hline $\mathrm{T} 4$ & -0.0719 & 0.1070 & 0.000008 & $\mathrm{QME}_{\mathrm{T} 2}=\mathrm{QME}_{\mathrm{T} 3}$ & $\mathrm{~B}_{\mathrm{T} 2}=\mathrm{b}_{\mathrm{T} 3}$ & $\mathrm{~A}_{\mathrm{T} 2}=\mathrm{a}_{\mathrm{T} 3}$ \\
\hline $\mathrm{T} 2$ & -0.0747 & 0.0928 & 0.000004 & $|0.88 \mathrm{Fc}|<1.84 \mathrm{Ft}$ & $|0.42 \mathrm{Tc}|<2.00 \mathrm{Tt}$ & $|0.02 \mathrm{Tc}|<2.00 \mathrm{Tt}$ \\
\hline $\mathrm{T} 5$ & -0.0720 & 0.1180 & 0.000005 & $\mathrm{QME}_{\mathrm{T} 2}=\mathrm{QME}_{\mathrm{T} 5}$ & $\mathrm{~B}_{\mathrm{T} 2}=\mathrm{b}_{\mathrm{T} 5}$ & $\mathrm{~A}_{\mathrm{T} 2}=\mathrm{aT} 5$ \\
\hline $\mathrm{T} 2$ & -0.0747 & 0.0928 & 0.000004 & $|0.92 \mathrm{Fc}|<1.88 \mathrm{Ft}$ & $|0.82 \mathrm{Tc}|<2.00 \mathrm{Tt}$ & $|0.02 \mathrm{Tc}|<2.0 \mathrm{Tt}$ \\
\hline $\mathrm{T} 6$ & -0.0693 & 0.1250 & 0.000004 & $\mathrm{QME}_{\mathrm{T} 2}=\mathrm{QME}_{\mathrm{T} 6}$ & $\mathrm{~B}_{\mathrm{T} 2}=\mathrm{b}_{\mathrm{T} 6}$ & $\mathrm{~A}_{\mathrm{T} 2}=\mathrm{a} \mathrm{T} 5$ \\
\hline $\mathrm{T} 3$ & -0.0673 & 0.1030 & 0.000007 & $|1.07 \mathrm{Fc}|<1.69 \mathrm{Ft}$ & $|0.50 \mathrm{Tc}|<1.98 \mathrm{Tt}$ & $|0.05 \mathrm{Tc}|<1.98 \mathrm{Tt}$ \\
\hline $\mathrm{T} 4$ & -0.0719 & 0.1070 & 0.000008 & $\mathrm{QME}_{\mathrm{T} 3}=\mathrm{QME}_{\mathrm{T} 4}$ & $\mathrm{~B}_{\mathrm{T} 3}=\mathrm{b}_{\mathrm{T} 4}$ & $\mathrm{~A}_{\mathrm{T} 3}=\mathrm{aT} 4$ \\
\hline T3 & -0.0673 & 0.1030 & 0.000007 & $|1.67 \mathrm{Fc}|<1.74 \mathrm{Ft}$ & $|0.01 \mathrm{Tc}|<1.98 \mathrm{Tt}$ & $|0.04 \mathrm{Tc}|<1.98 \mathrm{Tt}$ \\
\hline $\mathrm{T} 5$ & -0.0720 & 0.1180 & 0.000005 & $\mathrm{QME}_{\mathrm{T} 3}=\mathrm{QME}_{\mathrm{T} 5}$ & $\mathrm{~B}_{\mathrm{T} 3}=\mathrm{b}_{\mathrm{T} 5}$ & $\mathrm{~A}_{\mathrm{T} 3}=\mathrm{aT} 5$ \\
\hline $\mathrm{T} 3$ & -0.0673 & 0.1030 & 0.000007 & $|1.72 \mathrm{Fc}|<1.84 \mathrm{Ft}$ & $|0.29 \mathrm{Tc}|<2.00 \mathrm{Tt}$ & $|0.04 \mathrm{Tc}|<2.00 \mathrm{Tt}$ \\
\hline $\mathrm{T} 6$ & -0.0693 & 0.1250 & 0.000004 & $\mathrm{QME}_{\mathrm{T} 3}=\mathrm{QME} \mathrm{T} 6$ & $\mathrm{~B}_{\mathrm{T} 3}=\mathrm{b}_{\mathrm{T} 6}$ & $\mathrm{~A}_{\mathrm{T} 3}=\mathrm{aT} 6$ \\
\hline $\mathrm{T} 4$ & -0.0719 & 0.1070 & 0.000008 & $|1.40 \mathrm{Fc}|<1.79 \mathrm{Ft}$ & $|0.60 \mathrm{Tc}|<1.98 \mathrm{Tt}$ & $|0.02 \mathrm{Tc}|<1.98 \mathrm{Tt}$ \\
\hline $\mathrm{T} 5$ & -0.0720 & 0.1180 & 0.000005 & $\mathrm{QME}_{\mathrm{T} 4}=\mathrm{QME}_{\mathrm{T} 5}$ & $\mathrm{~B}_{\mathrm{T} 4}=\mathrm{b}_{\mathrm{T} 5}$ & $\mathrm{~A}_{\mathrm{T} 4}=\mathrm{aT} 5$ \\
\hline $\mathrm{T} 4$ & -0.0719 & 0.1070 & 0.000008 & $|1.60 \mathrm{Fc}|<1.84 \mathrm{Ft}$ & $|0.25 \mathrm{Tc}|<1.98 \mathrm{Tt}$ & $|0.02 \mathrm{Tc}|<1.98 \mathrm{Tt}$ \\
\hline $\mathrm{T} 6$ & -0.0693 & 0.1250 & 0.000004 & $\mathrm{QME}_{\mathrm{T} 4}=\mathrm{QME}_{\mathrm{T} 6}$ & $\mathrm{~B}_{\mathrm{T} 4}=\mathrm{b}_{\mathrm{T} 6}$ & $\mathrm{~A}_{\mathrm{T} 4}=\mathrm{aT} 6$ \\
\hline $\mathrm{T} 5$ & -0.0720 & 0.1180 & 0.000005 & $|1.04 \mathrm{Fc}|<1.88 \mathrm{Ft}$ & $|0.38 \mathrm{Tc}|<2.00 \mathrm{Tt}$ & $|0.04 \mathrm{Tc}|<2.00 \mathrm{Tt}$ \\
\hline $\mathrm{T} 6$ & -0.0693 & 0.1250 & 0.000004 & $\mathrm{QME}_{\mathrm{T} 5}=\mathrm{QME}_{\mathrm{T} 6}$ & $\mathrm{~B}_{\mathrm{T} 5}=\mathrm{b}_{\mathrm{T} 6}$ & $\mathrm{~A}_{\mathrm{T} 5}=\mathrm{aT} 6$ \\
\hline
\end{tabular}

T: treatments, RMS: Residual Mean Square, "b": angular coefficient, "a": linear coefficient, $\mathrm{F}_{\mathrm{c}}$ : calculated $\mathrm{F}$ value, $\mathrm{F}_{\mathrm{t}}$ : critical point of the F-Snedecor table, $\mathrm{T}_{c}$ : calculated $\mathrm{T}$ value, $\mathrm{T}_{\mathrm{T}}$ : critical value of the two-tail t-Student table, ns: non-significant difference at $5 \%$, *: significant different at $5 \%$. 


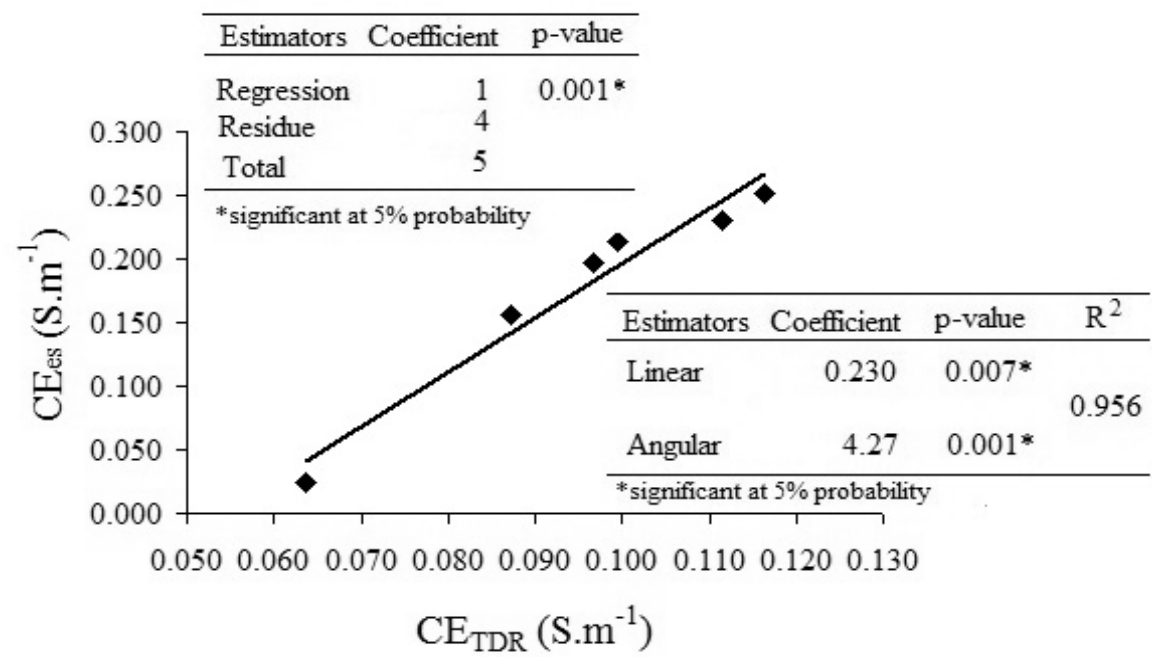

Figure 6. Regression model of the soil electric conductivity by the soil saturated extract method $\left(\mathrm{EC}_{\mathrm{es}}\right)$ and apparent electric conductivity determined by TDR $\left(\mathrm{EC}_{\mathrm{TDR}}\right)$.

\section{CONCLUSIONS}

1. A new equation was established for TDR Trase $6050 \mathrm{X} 1$ and the handmade probes used in the evaluation of a Rhodic Acrudox soil.

2. The $\beta$ Coefficient can be used to indirectly estimate $\mathrm{EC}_{\mathrm{TDR}}$.

3. The linear models fitted for $\theta_{\mathrm{S}}$ and $\mathrm{EC}_{\mathrm{TDR}}$ were statistically equal for all treatments.

4. It was possible to establish an empirical equation to determine $\mathrm{EC}_{\mathrm{se}}$ of a Rhodic Acrudox soil, irrigated with swine wastewater, using TDR.

\section{LITERATURE CITED}

CICHOTA, R. Avaliação do campo de um TDR segmentado para determinação de umidade no solo. Piracicaba, Escola Superior de Agricultura Luiz de Queiroz, 2003. 121p.

COELHO, E.F.; VELLAME, L.M. \& COELHO FILHO, M.A. Sondas de TDR para estimativa da umidade e condutividade elétrica do solo, com uso de multiplexadores. AGRIAMBI, 9:475-480, 2005.

DALTON, F.N.; HERKELRATH, W.N.; RAWLINS, D.S. \& RHOADES, J.D. Time-domain reflectometry: Simultaneous measurement of soil water content and electrical conductivity with a single probe. Science, 224:989-990, 1984.

EMPRESA BRASILEIRA DE PESQUISA AGROPECUÁRIA EMBRAPA. Manual de métodos de análise de solo. 2.ed. Rio de Janeiro, Centro Nacional de Pesquisas de Solos, 1997. 221p.

GIESE, K. \& TIEMANN, R. Determination of the complex permittivity from a thin sample time-domain reflectometry, improved analysis of the step response waveform. Adv. Molec. Relaxation Proc., 7:45-59, 1975.
GOMES, F.P. Curso de estatística experimental. 14.ed. São Paulo, Nobel, 2000.477p.

HAMED, Y.; PERSSON, M. \& BERNDTSSON, R. Soil solution electrical conductivity measurements using different dielectric techniques. Soil Sci. Soc.Am. J., 67:1071-1078, 2003.

JONES, B.S. \& OR, D. Frequency domain analysis for extending time domain reflectometry water content measurement in highly saline soils. Soil Sci. Soc.Am. J., 68:1568-1577, 2004.

MONTGOMERY, D.C. Introdução ao controle estatístico da qualidade. 4.ed. Rio de Janeiro, LTC, 2004.

NADLER, A. Relations between soil and tree stem water content and bulk electrical conductivity under salinizing irrigation. Soil Sci. Soc.Am. J., 68:779-783, 2004.

OR, D.; JONES, S.B.; VANSHAAR, J.R.; WRAITH, J.M.; HUMPHRIES, S. \& KOBERSTEIN, L. WinTDR 6.0 Users guide. 2004. Disponível em: <http://soilphysics.usu.edu/ wintdr/Documents/ Manuals/ 2004Fall/ WinTDRManual_Fall2004.pdf> Acesso em: 25 de maio de 2008.

PAGANINI, W.S. Reúso de água na agricultura. In: MANCUSO, P.C.S. \& SANTOS, H.F., eds. Reúso de agua. Barueri, Manole, 2003. p.339-402.

QUEIROZ, S.O.P.; TESTEZLAF, R. \& MATSURA, E.E. Avaliação de equipamentos para determinação da condutividade elétrica do solo. Irriga, 10:279-287, 2005.

RHOADES, J.D. Salinity: Electrical conductivity and total dissolved solids. In: Methods of Soil Analysis. Madison, Soil Science Society of America, 1996. Part 3. p.417-435. (SSSA Book Series, 5)

ROBINSON, D.A.; JONES, S.B.; WRAITH, J.M.; OR, D. \& FRIEDMAN, S.P. A review of advances in dielectric and electrical conductivity measurement in soils using time domain reflectometry. Vadose Zone J., 2:444-475, 2003. 
SAMPAIO, S.C.; CAOVILLA, F.A.; OPAZO, M.A.U.; NÓBREGA, L.H.P.; SUSZEK, M. \& SMANHOTTO, A. Lixiviação de íons em colunas de solo deformado e indeformado. Eng. Agric., 30:150-159, 2010.

SANTORO, B.L.; SATO, L.M.; LOPES, L.N. \& SOUZA, C.F. Construção e validação de sondas de TDR para o monitoramento ambiental. In: CONBEA, 38., JuazeiroBA/Petrolina-PB, 2009. CD ROM.

SILVA, E.L. \& GERVÁSIO, E.S. Uso do instrumento TDR para determinação do teor de água em diferentes camadas de um Latossolo roxo distrófico. AGRIAMBI, 3:417-420, 1999.

SOUZA, C.F.; FAVARO, R.B.T.M.; FOLEGATTI, M.V.; DAROZ, T.H.C. \& SILVA, E.F.F. Uso da reflectometria no domínio do tempo (TDR) para a avaliar a distribuição do nitrato no volume molhado do solo sob fertirrigação. Magistra, 19:112-122, 2007.

SOUZA, C.F.; FOLEGATTI, M.V.; MATSURA, E.E. \& OR, D. Calibração da reflectometria no domínio do tempo (TDR) para a estimativa da concentração da solução no solo. Eng. Agric., 26:282-291, 2006.
SOUZA, C.F.; OR, D. \& MATSURA, E.E. A variable-volume TDR probe for measuring water content in large soil volumes. Soil Sci. Soc.Am. J., 68:25-31, 2004.

TAVARES, M.H.F.; BUSATA, O.J.; VILAS BOAS, M.A. \& ORO, A.L.T. Desenvolvimento de aplicativo para um equipamento TDR. Irriga, 11:543-552, 2006.

TOMMASELLI, J.T.G. \& BACCHI, O.O.S. Calibração de um equipamento de TDR para medida de umidade de solos. Pesq. Agropec. Bras., 36:1145-1154, 2001.

TOPP, G.C.; DAVIS, J.L. \& ANNAN, A.P. Electromagnetic determination of soil water content: measurements in coaxial transmission lines. Water Res. Res., 16:574-582, 1980 .

VILLWOCK, R.; TAVARES, M.H.F. \& VILAS BOAS, M.A. Calibração de um equipamento TDR em condições de campo. Irriga, 9:82-88, 2004. 